\title{
Nosocomial Methicillin Resistant Staphylococcus aureus Pneumonia - Epidemiology and Trends Based on Data of A Network of 586 German ICUs (2005-2009)
}

\author{
Elisabeth Meyer ${ }^{1,2}$, Frank Schwab1,2, Petra Gastmeier ${ }^{1,2}$ \\ ${ }^{1}$ Institute of Hygiene and Environmental Medicine, Charité - University Medicine Berlin, Berlin \\ ${ }^{2}$ National Reference Centre for Surveillance of Nosocomial Infections
}

\begin{abstract}
The epidemiology of MRSA pneumonia varies across countries. One of the most import risk factors for the development of nosocomial MRSA pneumonia is mechanical ventilation. Methicillin resistance in $S$. aureus ventilator associated pneumonia (VAP) ranged between $37 \%$ in German, $54 \%$ in the US American and $78 \%$ in Asian and Latin American ICUs. In 2009, the incidence density of nosocomial VAP caused by MRSA was 0.28 per 1000 ventilation days in a network of 586 German ICUs. Incidences peaked in neurological and neurosurgical ICUs. Crude hospital mortality in studies performed after 2005 lay between $27 \%$ and $59 \%$ and attributable MRSA pneumonia mortality at $40 \%$. Since 2005, US American and German data indicate decreasing trends for MRSA pneumonia. Measures to reduce MRSA pneumonia or to control the spread of MRSA include hand hygiene, standard and contact precautions, oral contamination with chlorhexidine, skin decontamination with antiseptics, screening, and (possibly) patient isolation in a single room.
\end{abstract}

Key words: methicillin resistant Staphylococcus aureus, pneumonia, nosocomial, mortality, risk factor, age, change over time

\section{INTRODUCTION}

Pneumonia is the second most common hospital-acquired (nosocomial) infection; in intensive care units (ICU) it ranges even first $[1,2]$. The prevalence of pneumonia varies, with an incidence ranging from $7 \%$ to more than $40 \%$. In ventilated patients, rates of pneumonia may be between 6 and 21 times higher than in other patients, and the risk increases by $1 \%$ for each day the patient requires tracheal intubation [3]. It is associated with prolonged hospital stays and a high mortality rate and it differs by type of pathogen $[4,5]$.

S. aureus is one of the most frequently isolated pathogens in nosocomial pneumonia and is problematic due to its ubiquity (with up to $50 \%$ persistent or intermittent colonized adults and colonized persons being at increased risk for subsequent infection) and its production of extracellular enzymes and toxins, which function as virulence factors.

MRSA is even more problematic because therapeu- tic options to treat MRSA infections are limited because MRSA tends to be multiresistant i.e. not only resistant to all $\beta$-lactams but also to other antibiotic classes such as the fluoroquinolones.

The aim of our study was to give an overview on nosocomial MRSA pneumonia focusing on the epidemiology and to present current ventilator-associated pneumonia data of a network of 586 German ICUs.

\section{Epidemiology}

Based on the data of the German national nosocomial infection surveillance system (KISS) about 20,000 ventilator associated lower respirator tract infections can be expected annually in German intensive care units, among them about 16,000 cases of ventilator associated pneumonia (VAP) [6]. $20 \%$ of these cases are due to $S$. aureus, and $37 \%$ of them are methicillin resistant (Table 1). This means that about 1,200 ventilatorassociated pneumonia (VAP) cases due to MRSA can be expected every year in German ICUs. Projecting these figures to the whole European Union would result in about 7,500 VAP cases with MRSA on European ICUs annually.

The mean VAP rate in medical-surgical ICUs was 2.2 per 1000 ventilator days in US-American ICUs (2006-2008); it was higher with 4.8 in German ICUs (2005-2009) and was highest with 14.7 in ICUs participating in the International Infection Control Consortium (INICC) [7, 8]. INICC was founded in Argentina. Countries providing data to INICC from $n>10$ ICUs are located in Argentina, Brazil, Colombia, India, Mexico, Peru and Turkey.

Interestingly, $S$. aureus ranged first as causing pathogen in the USA and in Germany and accounted for $24.4 \%$ and $19.8 \%$ of the VAP cases, but it ranged only third after Pseudomonas and Acinetobacter in the Latin-American and Asian ICUs (Table 1) [9]. Only recently there is increasing evidence that temperature and seasonality influences infection and colonization with Gram-negatives [10-12]. Although S. aureus was isolated in a smaller proportion in ICUs from Asia and Latin-America the percentage of MRSA on the total of VAP cases caused by $S$. aureus was extremely high with $77.5 \%$. More than half of the $S$. aureus pneumonia cases in US-ICUs were methicillin resistant, whereas only one third in German ICUs. 


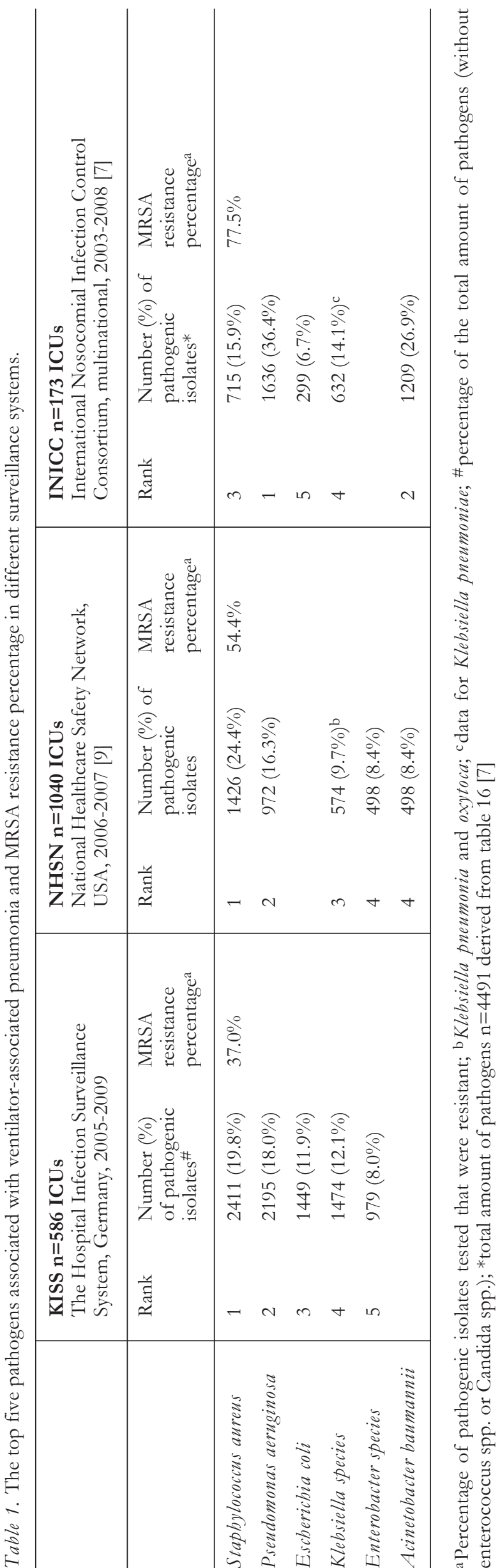

Therefore, data on the epidemiology of MRSA pneumonia differ by geographic region and generalization has to be done with caution and might be misleading.

Furthermore, it was in the 1990s when MRSA emerged as a community-associated pathogen. Especially in the United States community-associated MRSA strains have increasingly caused hospital-onset and health care-associated, community-onset infections [13]. The initial USA400 strains that predominated before 2001 have now been replaced by the unrelated USA300 strains that currently cause the majority of community-associated MRSA infections [14]. In some countries like the US, Canada or Greece, MRSA is increasing in the community and, in some cases, is replacing "nosocomial" MRSA in hospitals $[15,16]$.

Epidemiological data on nosocomial pneumonia in non-ICU patients are scare and it remains unclear whether or not data from ICU patients can be used in analogy. One of the few multicenter studies on nosocomial pneumonia in non-ICUs patients revealed that S. pneumoniae accounted for $27 \%$ (16 out of $59 \mathrm{pa}-$ tients) but $S$. aureus for only $7 \%$ (4 patients; one MRSA) of nosocomial pneumonia in patients where a pathogen could be isolated [17]. The authors discussed that patients in conventional hospital wards are not exposed to such invasive manoeuvres as patients receiving mechanical ventilation; thus, changes in the oropharyngeal flora are probably delayed and the community flora persists longer in them. Accordingly, it can be hypothesized that microorganisms responsible for pneumonia acquired in the general hospitalization wards may differ from those implicated in VAP.

But, incidence densities on VAP caused by $S$. aureus and MRSA differ even by type of ICU as shown in Figure 1. In neurosurgical and neurological ICUs $S$. aureus was found in about one third of all VAPs whereas it played only a minor role as causative pathogen in cardiothoracic ICUs. The reason for this might be the higher proportion of patients with heavy aspiration (including aspiration of the nasopharyngeal flora which serves as the reservoir of $S$. aureus) due to neurotrauma or dysphagia in neurological and neurosurgical wards. The comparably small incidence in cardiothoracic ICUs might be explained by perioperative prophylaxis with glycopeptides in centers with a high endemic MRSA situation.

\section{Cause, Pathophysiology and Risk FACTORS}

MRSA like other bacteria can reach the lower respiratory tract to cause pneumonia by four routes: aspiration, inhalation, contiguous spread and haematogenous spread. Aspiration is the main route used by bacteria to invade the lower airways and cause VAP. Haematogenous or contiguous routes of invasion are very rare.

The impact of $S$. aureus on the airways, from asymptomatic colonisation to severe pneumonia, depends on the interplay of patient, bacterial and environmental factors. Colonisation of the lower respira- 


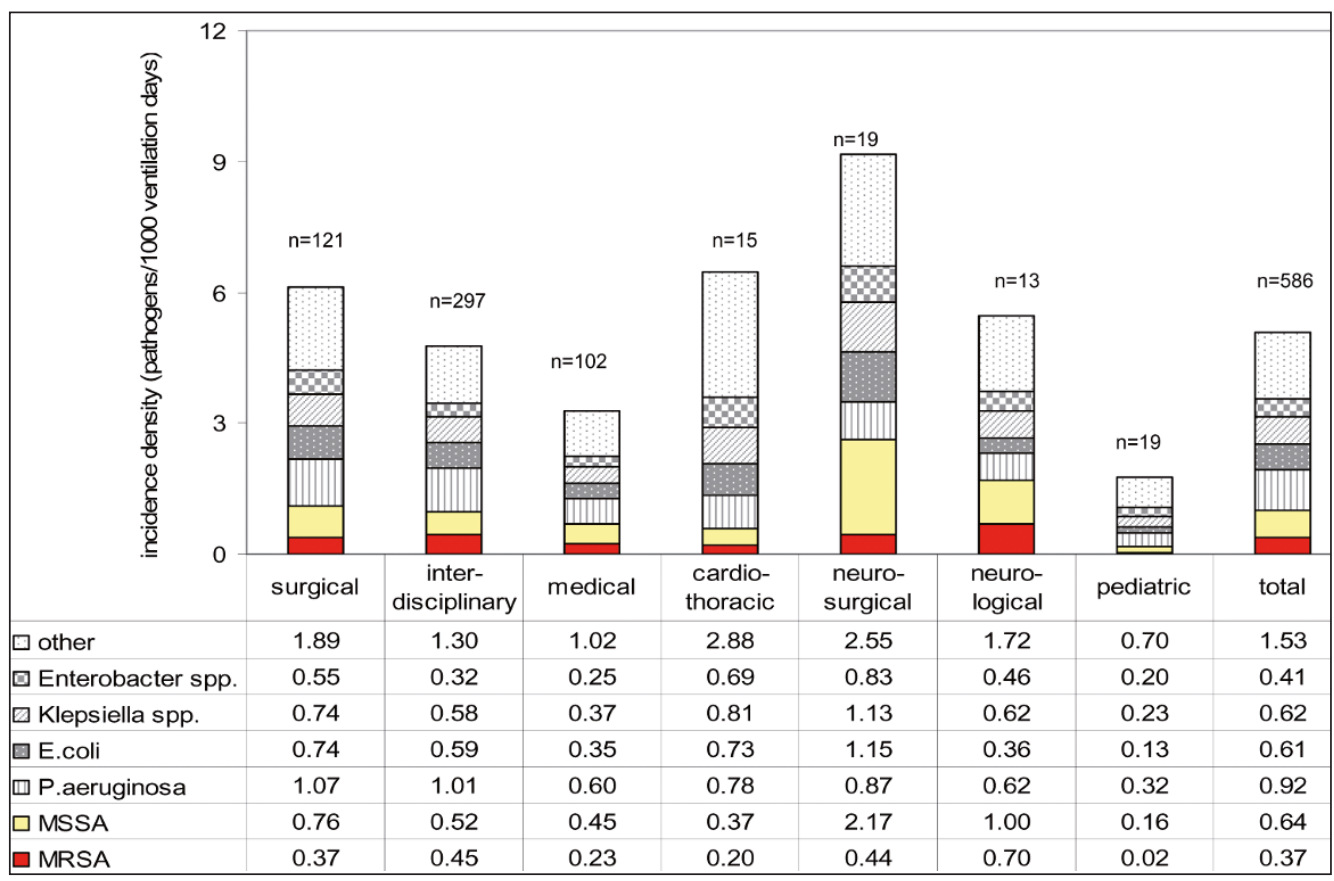

MSSA methicillin susceptible S. aureus; n number ICUs.

Fig. 1. Incidence density of most frequently isolated pathogens associated with ventilator associated pneumonia per 1000 ventilator days by type of intensive care unit, 586 German ICUs, 2005-2009. Fig. 1. Incidence density of most frequently isolated pathogens associated with ventilator associated pneumonia per 1000 ventilator days by type of intensive care unit, 586 German ICUs, 2005-2009.

tory tract by $S$. aureus (MRSA) can occur in the setting of chronic pulmonary disease [18]. Although this colonisation may be asymptomatic, it paves the way for overt infection, i.e. pneumonia, if the balance between host defence and bacterial virulence is shifted in the favour of bacteria. Colonisation can also occur due to breaches in natural defences, such as endotracheal intubation. Those patients are sedated, or even paralyzed, and cannot cough efficiently. The secretions pool above the inflated endotracheal tube cuff and can be aspirated if not drained effectively. Patients with head injury and trauma who have nasopharyngeal carriage of $S$. aureus are at increased risk of $S$. aureus pneumonia. Staphylococcal pneumonia may also develop after influenza infection or after novel H1N1 influenza, which seems to occur preferentially among young adults (in whom mortality reaches 50 $\%$ ) [19].

Known risk factors for MRSA infection in general encompass prior antibiotic use especially the use of quinolones, enteral feeding, surgery and previous hospitalization [20]. The time from ICU admission to infection differed significantly between MSSA and MRSA in our network of 586 ICUs: it was 14 days for VAP caused by MRSA but only 8 days for VAP caused by MSSA. Other studies found even more prominent differences in the length of hospital stay until the onset of pneumonia (4 days for MSSA and 11.5 days for MRSA) [21].

\section{Age and Mortality}

In most studies performed before 2005, patients with MRSA pneumonia were older than patients with MSSA pneumonia (Table 2). Whether a greater number of older patients with severe underlying diseases or other patient differences have an impact of methicillin resistance on morbidity and mortality among patients with S. aureus pneumonia remains highly controversial. For bacteraemia the increased mortality was shown in two meta-analyses [22, 23], and the enormous influence on morbidity and hospital costs was also demonstrated for surgical site infections [24]. But for pneumonia it is still debated whether MRSA causing VAP is an independent risk factor for adverse outcomes.

Rello et al. found a significantly higher mortality for MRSA pneumonia in comparison to methicillin susceptible $S$. aureus (MSSA) pneumonia [25]. Other authors though, did not find that MRSA infections significantly influenced mortality rates [26-28]. DeRyke reported that although fewer patients with MRSA pneumonia received appropriate treatment $(50 \%)$ than patients with MSSA pneumonia (72\%) neither the hospital mortality differed, nor infection related mortality nor infection related length of stay [21]. A systematic review to determine the effect of methicillin resistance on mortality including eight articles was published in 2008 [29]. Crude in-hospital mortality was higher in patients with VAP due to MRSA than in those with VAP due to methicillin sensitive $S$. aureus. Likewise in our network of KISS ICU the crude ICU fatality was significantly lower for VAP caused by MSSA than by MRSA (Table 2). However, adjustment for risk factors suggests that this association may not be causal, but probably due to confounders, such as the adequacy of empirical treatment and severity of illness. This is underlined by the fact that two recent studies with results on infection related mortality did not reveal a significant difference [21, 27]. 


\begin{tabular}{|c|c|c|c|c|c|c|c|c|c|c|c|c|c|}
\hline 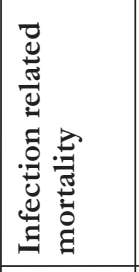 & 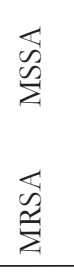 & & & & & $\begin{array}{l}\stackrel{\circ}{\circ} \\
\frac{\circ}{7}\end{array}$ & & & & & & $\begin{array}{c}\stackrel{\circ}{F} \\
\stackrel{7}{\circ} \\
\stackrel{\circ}{\circ}\end{array}$ & ڤิ̀ \\
\hline 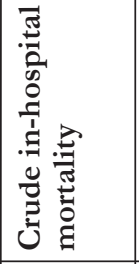 & 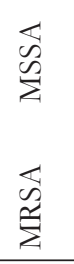 & $\begin{array}{l}\text { ठें } \\
\text { ڤें }\end{array}$ & $\begin{array}{l}\stackrel{+}{*} \\
\stackrel{+}{*} \\
\stackrel{+}{*}\end{array}$ & $\begin{array}{l}\stackrel{\circ}{\grave{D}} \\
\# \\
\stackrel{\circ}{\circ}\end{array}$ & $\begin{array}{l}\text { 仓ें } \\
\stackrel{\text { ลें }}{ }\end{array}$ & $\begin{array}{l}\text { iें } \\
\text { in } \\
\text { in }\end{array}$ & 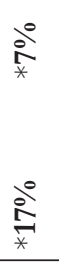 & 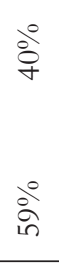 & $\begin{array}{l}\text { बें } \\
\text { केे }\end{array}$ & 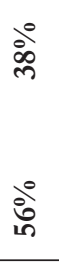 & $\begin{array}{l}\text { 亏ें } \\
\text { लें }\end{array}$ & & \\
\hline 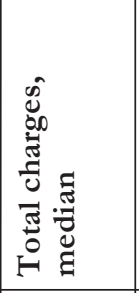 & 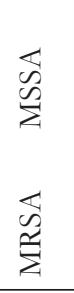 & 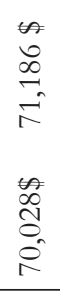 & & 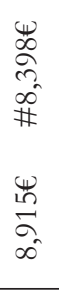 & 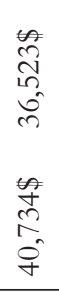 & & & & & & & & \\
\hline 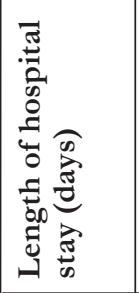 & 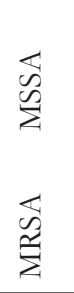 & $\exists$ & & $\stackrel{9}{\#}$ & $\begin{array}{l}\stackrel{ }{\rightarrow} \\
\stackrel{\mathrm{N}}{ }\end{array}$ & $\begin{array}{l}\stackrel{0}{<} \\
\stackrel{2}{r}\end{array}$ & & & $\begin{array}{c}\hat{\circ} \\
\text { ণ }\end{array}$ & & & & \\
\hline 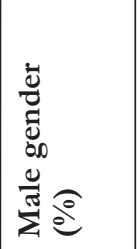 & 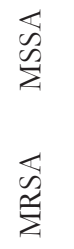 & $\begin{array}{l}\text { ठें } \\
\text { oें }\end{array}$ & $\begin{array}{l}\stackrel{\circ}{\mathrm{i}} \\
\text { ㅇํㅇ }\end{array}$ & 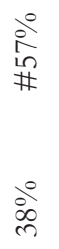 & $\begin{array}{l}\text { लें } \\
\text { ㅇํ }\end{array}$ & & & 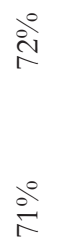 & $\begin{array}{l}\text { ํํे } \\
\text { iे }\end{array}$ & $\begin{array}{l}\stackrel{े}{1} \\
\stackrel{0}{\circ}\end{array}$ & & ìं & $\begin{array}{l}\text { ठें } \\
\frac{\circ}{\infty}\end{array}$ \\
\hline 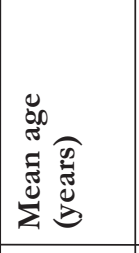 & 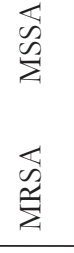 & 8 & $\begin{array}{l}8 \\
8\end{array}$ & 命 & 5 & 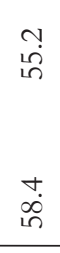 & & 8 & $\stackrel{\infty}{n}$ & 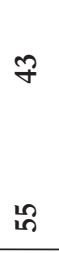 & & in & F \\
\hline 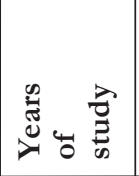 & & 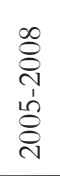 & 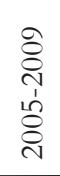 & 孛 & 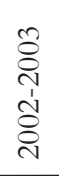 & 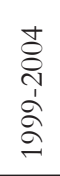 & 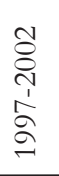 & 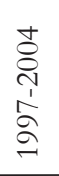 & & \begin{tabular}{l}
\multirow{2}{\sigma}{} \\
$\frac{1}{\grave{2}}$ \\
aे
\end{tabular} & & 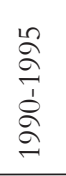 & $\frac{\Re}{\stackrel{a}{a}}$ \\
\hline 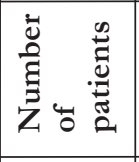 & & $\stackrel{\text { ㄱ }}{\sim}$ & $\underset{\vec{g}}{\vec{F}}$ & $\stackrel{\text { F }}{\text { f }}$ & $\stackrel{\text { 芫 }}{\sim}$ & 8 & $\begin{array}{l}\overrightarrow{i n} \\
\infty \\
\rightarrow \\
\rightarrow\end{array}$ & $\stackrel{+}{\sim}$ & $\Xi$ & $\hat{\vartheta}$ & $\stackrel{\stackrel{\circ}{N}}{\sim}$ & $\infty$ & $\mathscr{f}$ \\
\hline 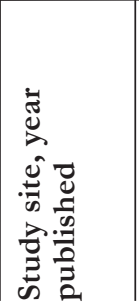 & & 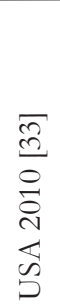 & 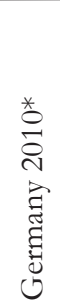 & 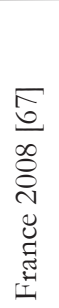 & 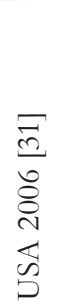 & 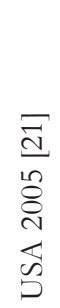 & 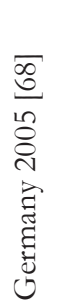 & 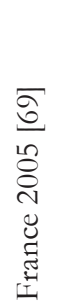 & 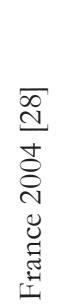 & 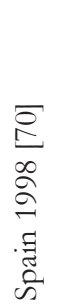 & 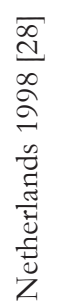 & 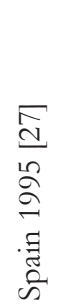 & 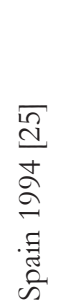 \\
\hline
\end{tabular}


Vidaur et al. demonstrated that VAP due to MRSA required significantly longer respiratory support than VAP due to other organisms [30]. Shorr et al. showed also that MRSA patients on average consumed excess resources of 4.4 overall mechanical ventilation days, 3.8 days of inpatient length of stay, 5.3 ICU days and US 7,731 dollars total costs after controlling for case mix and other factors [31]. Interestingly, the same author published 5 years later that total charges for MRSA health care associated pneumonia were even lower than those for MSSA pneumonia. However, total cost almost doubled within 5 years for MRSA as well as for MSSA pneumonia [32, 33].

In general, the outcome of patients with pneumonia due to either MRSA or MSSA is associated with a significant morbidity, mortality, and health care cost, even when the initial antibiotic therapy is adequate.

\section{Change Over Time}

A recent study by Kallen et al. on health care associated invasive MRSA infections in the USA, 2005-2008, suggests that there may be an ongoing decrease in MRSA as a cause of human infection, particularly in non community settings [34]. The incidence rate of hospital-onset invasive MRSA infections was 1.02 per 10,000 population in 2005 and decreased by $9.4 \%$ per year. The decrease was most prominent MRSA blood stream infections but it was also statistically significant for hospital onset of pneumonia or emphysema due to MRSA. The National Healthcare Safety Network report states that the ranking of the 4 most common pathogens was in 2006-2007 almost identical to that in the NNIS report published in 1999 for VAP [9, 35].
The exception was A. baumannii that equalled lastly Enterobacter species for VAP; $S$. aureus remained in the first position.

In the ICUs participating in KISS there was no change towards more Gram-negatives or Gram-positives in the incidence density of VAP pneumonia over the last five years (Fig. 2). $S$. aureus ranged first as causing pathogen from 2005-2009 and the proportion of MRSA stayed stable accounting for about one third of all $S$. aureus isolates. Generally, the incidence density of nosocomial VAP declined (from 5.81 in 2005 to 4.33 VAP per 1000 ventilation days in 2009) but the decline affected all pathogens (from 5.76 in 2005 to 4.21 VAP-pathogens per 1000 ventilation days in 2009). Likewise reported Moalla et al. no trends in the incidence of nosocomial MRSA pneumonia in a French University hospital over a period of 4 years: it was 0.9 cases per 1000 patient days in 2003 and was 0.7 in $2006(p=.26)$ [36].

\section{Antibiotic Therapy AND IMPACT ON EPIDEMIOLOGICAL PARAMETERS}

Pneumonia caused by MRSA has been recognized as a difficult to treat infection because of the limited choice of therapy and prolonged duration of treatment. Antibiotic therapy is needed for more than 14 or even 21 days in patients without rapid resolution of symptoms, in bacteremic patients with metastatic infections, with empyema or caverns [37]. Currently, only vancomycin and linezolid are approved for therapy of MRSA pneumonia in the USA, in some European countries also teicoplanin and quinupristin / dalforpristin [38].

\begin{tabular}{|cc|r|r|r|r|r|r|}
\hline & \\
\hline
\end{tabular}

Crude ICU-mortality in patients with MRSA associated VAP was $24.6 \%, 26.9 \%, 24.9 \%, 32.1 \%$ and $26.3 \%$ for the years 2005 to 2009.

MSSA methicillin susceptible S. aureus, VAP ventilator-associated pneumonia

Fig. 2. Incidence densities (pathogens per 1000 ventilator days) and proportion of the most frequently isolated pathogens in ventilator associated pneumonia, 586 German ICUs, 2005-2009 
In 2010, a meta-analysis of randomized controlled trials compared linezolid to gycopeptides for MRSA nosocomial pneumonia [39]. The results did not support the assertion that linezolid is a more efficacious antibiotic. Clinical and microbiological outcomes in patients randomized to linezolid were not superior to patients randomized to glycopeptides. Furthermore, adverse events were not statistically different between the two antibiotics. The authors argue against widespread routine use of linezolid for suspected nosocomial MRSA pneumonia based on the presumption of superior efficacy. They recommend that decisions between linezolid or glycopeptide antibiotics for empiric or MRSA-directed therapy of nosocomial pneumonia depend on local availability, antibiotic resistance patterns, preferred routes of delivery, and cost (about tenfold increase in cost per dose linezolid), rather than presumed differences in efficacy.

Older agents such as fosfomycin, rifampicin and fusidic acid in combination with vancomycin are theoretically effective. This has been supported by recent studies [40, 41]; however, clinical trials from randomized controlled trials are lacking and will probably never be performed because of absent incentive for the pharmaceutical industry (relatively inexpensive antibiotics).

Whether or not the approval of linezolid in 2000 or other new anti-MRSA antibiotics had an impact on the epidemiology of MRSA remains unclear. A large-scale Canadian study included a 1.2 million population in the province of Alberta, Canada, over a period of 7 years and monitored bacteremic $S$. aureus infection: The incidence of, and outcomes associated with $S$. aureus bacteremia have not significantly changed during 2000-2006. The overall annual incidences for bacteremia due to MSSA or MRSA, were 17.5 and 2.2 cases/100,000 population/year, respectively. Although rates of both health care-associated community onset and nosocomial MSSA bacteremia were not significantly different throughout the duration of the study, rates of community acquired MSSA bacteremia gradually decreased $(p=.01)$. But, rates of MRSA bacteremia increased $(\mathrm{p}=<.001)$. Likewise, the population mortality rate associated with MRSA bacteremia was increasing during the study, however no significant overall increase in the rate of death due to $S$. aureus bacteremia was observed [16].

In our data, crude ICU mortality due to MRSA pneumonia did not decrease from 2005 to 2009. It was $24.6 \%$ in 2005 and $26.3 \%$ in 2009 . The overall incidence density for nosocomial VAP decreased, but the proportion of VAP due to MRSA or MSSA stayed stable (Table 2).

\section{Prevention of MRSA Pneumonia}

One of the most important risk factors for the development of nosocomial pneumonia is mechanical ventilation because the endotracheal tube holds the vocal cords open and facilitates aspiration. All measures to reduce VAP will have an impact also on MRSA pneumonia as well as all measures to prevent transmission of MRSA in the hospital.

\section{Bundle Approach For the Prevention of VAP}

A number of different care bundles have previously been implemented to prevent VAP. The most commonly used is supported by the 100,000 Lives Campaign and comprises interventions of: Elevation of the head of the bed to between 30 and 45 degrees, daily sedation vacation and daily assessment of readiness to extubate, peptic ulcer disease prophylaxis and deep vein thrombosis prophylaxis (unless contraindicated). This care bundle has reported considerable success in reducing the incidence of VAP [42, 43]. However, certain recommendations are not strongly supported by the available evidence or do not directly target VAP. Addressing this point, an European care bundle for prevention of ventilator-associated pneumonia was published only recently focusing on 5 points [44]: (1) Not implementing ventilatory circuit changes unless specifically indicated (2) the use of strict hand hygiene using alcohol (3) the use of appropriately educated and trained staff (4) the incorporation of sedation vacation and weaning protocols into patient care and (5) oral care with chlorhexidine.

\section{Oral Care with Chlorhexidine (Rinse or Gel)}

Colonization of the oropharyngeal cavity with potentially pathogenic micro-organisms is instrumental in the pathogenesis of VAP, and oropharyngeal decontamination with antiseptics, such as chlorhexidine gluconate has been associated with reduced incidences of VAP. Chlorhexidine has a broad range of activity against gram-positive microorganisms, including multiresistant pathogens such as methicillin-resistant $S$. aureus (MRSA) [45]. Koeman et al. found a risk reduction of VAP by $65 \%$ if oral decontamination was done with chlorhexidine in comparison to placebo [46]. The combination of chlorhexidine and colistin provided significant reduction in oropharyngeal colonization with both gram-negative and gram-positive microorganisms, whereas chlorhexidine alone mostly affected gram-positive microorganisms. Likewise, Scannapieco and colleagues investigated differences in oropharyngeal colonization between mechanically ventilated patients receiving oropharyngeal decontamination with oral topical $0.12 \%$ chlorhexidine either once or twice daily compared to placebo. Chlorhexidine did reduce the number of $S$. aureus in dental plaque of trauma intensive care patients, but the study was underpowered to demonstrate a reduction in VAP incidence [47].

\section{Skin DeCONTAMINATION}

The two most commonly used decolonization agents are mupirocin for nasal carriage and chlorhexidine for skin carriage [48]. Recent studies have identified decolonization with agents such as chlorhexidine and mupirocin as having an important and perhaps underappreciated role in reducing ICU MRSA transmission: Evens et al. could demonstrate that daily bathing of trauma patients with cloths impregnated with $2 \%$ chlorhexidine gluconate is associated with a decreased rate of colonization by MRSA. And even more impor- 
tant, patients who received chlorhexidine baths were less likely to develop MRSA VAP (1.6 versus 5.7 infections per 1000 ventilator-days, $P=0.03$ ) [49]. Climo et al. implemented in 6 ICUs daily bathing with chlorhexidine. The overall rate of MRSA acquisition decreased $32 \%$ during the intervention period in comparison with the baseline period [50]. It can be theorized that reduced microbial density on a patient's skin led to decreased transmission to a healthcare worker's hands and thereby prevented subsequent transmission to additional patients. From the available literature octenidine appears to be as effective as chlorhexidine for MRSA decolonization with fewer adverse effects, but large randomised trials incorporating octenidine as a skin disinfectant for MRSA decolonization are not jet undertaken [51].

\section{Hand Hygiene and Adequate Staffing Levels}

Already during the sixties several investigations studied the spread of $S$. aureus in hospitals. They identified the spread via the hands of the staff as the most important way of transmission, and described the airborne way as less important [52]. Therefore proper hand hygiene is the crucial method for preventing the spread of MRSA in hospitals. This was confirmed by a cohort study by Grundmann et al. to identify exposures associated with cases that likely were the result of cross-transmission (i.e., occurring in clusters and with indistinguishable MRSA macrorestriction profiles) [53]. Fitting a simple stochastic model to the ascertained data allowed prediction of the effectiveness of infection control measures. Exposure to relative staff deficit was the only factor significantly associated with potential transmission $(\mathrm{P}=.001)$ and it was predicted that a $12 \%$ improvement in adherence to hand-hygiene policies might have compensated for staff shortage and prevented transmission during periods of overcrowding, shared care, and high workload. Pittet et al. were able to demonstrate a significant reduction of MRSA transmission rates in their hospital by increasing the compliance to hand hygiene substantially [54]. Meanwhile further studies demonstrated the close association between increasing alcoholic hand rub consumption and decreasing MRSA rates [55].

\section{Patient Screening}

Active surveillance cultures have been proposed to identify MRSA carriers. Carriers can receive contact precautions and, if needed, decontamination, with the objective not only of decreasing their individual risk of infection but also of diminishing the reservoir and, consequently, the risk of cross-transmission. In addition, knowledge of MRSA carriage can be helpful for appropriate empiric or prophylactic antibiotic therapy [56].

Robinsec et al. performed an observational study on universal MRSA screening in 3 hospitals over a 3.5-year period, and the rate of MRSA disease decreased significantly [57]. In contrast, MRSA rate did not decrease significantly during the intervention in 8 surgical units, where screening was performed routinely at hospital admission, and MRSA carriers received contact precautions and were recommended for decolonization and prophylactic antibiotic therapy [58]. A meta-analysis on MRSA screening found a nearly significant $31 \%$ decrease in the infection rate; the use of rapid screening tests, however, was not found to be effective, compared with conventional culture-based methods [59]. The authors concluded that active screening for MRSA is more important than the type of test used. But, they warned policy makers to make a costly MRSA universal screening mandatory because of the limits and the heterogeneity of the available evidence.

\section{Health Care Workers Screening}

There is ongoing controversy about the role - as reservoirs, vectors, or victims - of health-care workers in transmission of MRSA. Albrich et al reviewed 127 investigations showing an average MRSA carriage rate of $4.6 \%$ among 33,318 screened health-care workers [60]. $5.1 \%$ had clinical infections. Risk factors included chronic skin diseases, poor hygiene practices, and having worked in countries with endemic MRSA. The authors recommend screening of health-care workers during outbreaks and during early stages of an institutional epidemic when MRSA prevalence is still low or when a new MRSA strain is propagating rapidly. If MRSA is detected from staff, decolonization procedures should be applied.

\section{Single RoOm ISOLATION AND ENVIRONMENTAL CleANing}

Many authors and guidelines recommend isolating patients with MRSA in single rooms in order to increase compliance with hand hygiene and further barrier precautions like use of masks and gowns under isolation conditions [61]. Cooper et al. reviewed the evidence for the effectiveness of different isolation policies and screening practices in reducing the incidence of MRSA colonization and infection in hospital in-patients. A total of 46 studies were included in their review. Most were interrupted time series, with few planned formal prospective studies. All but one reported multiple interventions; no well-designed study allows the role of isolation measures alone to be assessed. Despite major methodological weaknesses and inadequate reporting in published research the authors conclude that there is evidence that concerted efforts that include isolation can reduce MRSA even when endemic [62]. However, in 2005 spread of MRSA in ICUs was prospectively investigated. The authors concluded that moving MRSA-positive patients into single rooms or cohorted bays does not reduce cross-infection and they recommended re-evaluating isolation policies [63]. On the other hand, contact precautions are unlikely to help in a unit where compliance with hand hygiene is very low at baseline. Apart from that, many authors are concerned, that isolation in single rooms for infection control precautions lead to patient neglect and errors: Healthcare workers are half as likely to enter the rooms of patients in contact isolation, but are more likely to wash their hands after caring for them than after caring for patients not in isolation [64]. Stelfox et al. examined 
the quality of medical care by comparing the data of isolated and non-isolated patients and found that isolated patients experienced more preventable adverse events, expressed greater dissatisfaction with their treatment and had less documented care [65]. Many European countries have been using isolation measures for many years, but their MRSA rates continued to increase.

Healthcare workers can transmit MRSA via hands or not changed gloves but also after touching contaminated environmental surfaces, since MRSA can survive for months in the environment. Neely et al. tested staphylococci: they survived for at least 1 day on all fabrics and plastic. Staphylococcal viability was longest on polyester ( 1 to 56 days) and on polyethylene plastic $(22$ to $>90$ days) [71].

\section{CONCLUSION}

The epidemiology of MRSA pneumonia varies across countries. One of the most import risk factors for the development of nosocomial MRSA pneumonia is mechanical ventilation. Methicillin resistance in $\mathrm{S}$. aureus VAPs ranged between $37 \%$ in German, $54 \%$ in the US American and $78 \%$ in Asian and Latin American ICUs. In 2009, the incidence density of nosocomial VAP caused by MRSA was 0.28 per 1000 ventilation days in a network of 586 German ICUs. Incidences peaked in neurological and neurosurgical ICUs. Crude hospital mortality in studies performed after 2005 lay between 27 and $59 \%$ and attributable MRSA pneumonia mortality at $40 \%$. Since 2005, US American and German data indicate decreasing trends for MRSA pneumonia. Measures to reduce MRSA pneumonia or to control the spread of MRSA include hand hygiene, standard and contact precautions, oral contamination with chlorhexidine, skin decontamination with antiseptics, screening, and (possibly) patient isolation in a single room. Lucet et al. summarize that one of the keys to a successful strategy is leadership, which encourages health care workers to adhere to recommendations [56]. This factor probably makes a major contribution to the success of infection control interventions.

\section{LITERATURE}

1. Ruden H, Gastmeier P, Daschner FD, Schumacher M. Nosocomial and community-acquired infections in Germany. Summary of the results of the First National Prevalence Study (NIDEP). Infection 1997;25(4):199202.

2. Haley RW, Hooton TM, Culver DH, Stanley RC, Emori TG, Hardison CD, Quade D, Shachtman RH, Schaberg DR, Shah BV, Schatz GD. Nosocomial infections in U.S. hospitals, 1975-1976: estimated frequency by selected characteristics of patients. Am J Med1981; 70(4): 947-59.

3. Rello J, Diaz E. Pneumonia in the intensive care unit. Crit Care Med 2003;31(10):2544-51.

4. Rello J. Impact of nosocomial infections on outcome: myths and evidence. Infect Control Hosp Epidemiol 1999;20(6):392-4.

5. Heyland DK, Cook DJ, Griffith L, Keenan SP, BrunBuisson C. The attributable morbidity and mortality of ventilator-associated pneumonia in the critically ill pa- tient. The Canadian Critical Trials Group. Am J Resp Critl Care Med 2004 1999;159(4 Pt 1):1249-56.

6. Gastmeier P, Geffers C. [Nosocomial infections in Germany. What are the numbers, based on the estimates for 2006?]. Deutsche medizinische Wochenschrift 2008; 133(21):1111-5.

7. Rosenthal VD, Maki DG, Jamulitrat S, Medeiros EA, Todi SK, Gomez DY, Leblebicioglu H, Abu Khader I, Miranda Novales MG, Berba R, Ramírez Wong FM, Barkat A, Pino OR, Dueñas L, Mitrev Z, Bijie H, Gurskis V, Kanj SS, Mapp T, Hidalgo RF, Ben Jaballah N, Raka L, Gikas A, Ahmed A, Thu le TA, Guzmán Siritt ME; INICC Members. International Nosocomial Infection Control Consortium (INICC) report, data summary for 2003-2008, issued June 2009. Am J Infect Control; 38(2):95-104 e2.

8. Edwards JR, Peterson KD, Mu Y, Banerjee S, AllenBridson K, Morrell G, Dudeck MA, Pollock DA, Horan TC.National Healthcare Safety Network (NHSN) report: data summary for 2006 through 2008, issued December 2009. Am J Infect Control 2009;37(10):783805.

9. Hidron AI, Edwards JR, Patel J, Horan TC, Sievert DM, Pollock DA, Fridkin SK; National Healthcare Safety Network Team NHSN annual update: antimicrobial-resistant pathogens associated with healthcareassociated infections: annual summary of data reported to the National Healthcare Safety Network at the Centers for Disease Control and Prevention, 20062007. Infect Control Hosp Epidemiol 2008;29(11): 996-1011.

10. Perencevich EN, McGregor JC, Shardell M, Furuno JP, Harris AD, Morris JG Jr, Fisman DN, Johnson JA. Summer Peaks in the Incidences of Gram-Negative Bacterial Infection Among Hospitalized Patients. Infect Control Hosp Epidemiol 2008;29(12):1124-31.

11. Anderson DJ, Richet H, Chen LF, Spelman DW, Hung YJ, Huang AT, Sexton DJ, Raoult D. Seasonal variation in Klebsiella pneumoniae bloodstream infection on 4 continents. J Inf Dis 2008;197(5):752-6.

12. Kaier K, Frank U, Conrad A, Meyer E. Seasonal and Ascending Trends in the Incidence of Carriage of Extended-Spectrum beta-Lactamase-Producing Escherichia coli and Klebsiella Species in 2 German Hospitals. Infect Control Hosp Epidemiol. 2010;31(11):1154-9.

13. Klevens RM, Morrison MA, Nadle J, Petit S, Gershman K, Ray S, Harrison LH, Lynfield R, Dumyati G, Townes JM, Craig AS, Zell ER, Fosheim GE, McDougal LK, Carey RB, Fridkin SK; Active Bacterial Core surveillance (ABCs) MRSA Investigators. Invasive methicillin-resistant Staphylococcus aureus infections in the United States. JAMA 2007;298(15):1763-71.

14. Chambers HF, Deleo FR. Waves of resistance: Staphylococcus aureus in the antibiotic era. Nature reviews 2009; 7(9):629-41.

15. Chini V, Petinaki E, Foka A, Paratiras S, Dimitracopoulos G, Spiliopoulou I. Spread of Staphylococcus aureus clinical isolates carrying Panton-Valentine leukocidin genes during a 3-year period in Greece. Clin Microbiol Infect 2006;12(1):29-34.

16. Laupland KB, Ross T, Gregson DB. Staphylococcus aureus bloodstream infections: risk factors, outcomes, and the influence of methicillin resistance in Calgary, Canada, 2000-2006. J Infect Dis 2008;198(3):336-43.

17. Sopena N, Sabria M. Multicenter study of hospital-acquired pneumonia in non-ICU patients. Chest 2005; 127(1):213-9.

18. Defres S, Marwick C, Nathwani D. MRSA as a cause of lung infection including airway infection, community- 
acquired pneumonia and hospital-acquired pneumonia. Eur Respir J 2009;34(6):1470-6.

19. Rothberg MB, Haessler SD. Complications of seasonal and pandemic influenza. Crit Care Med 2010;38(4 Suppl):e91-7.

20. Graffunder EM, Venezia RA. Risk factors associated with nosocomial methicillin-resistant Staphylococcus aureus (MRSA) infection including previous use of antimicrobials. J Antimicrob Chemother 2002;49(6):999-1005.

21. DeRyke CA, Lodise TP, Jr., Rybak MJ, McKinnon PS. Epidemiology, treatment, and outcomes of nosocomial bacteremic Staphylococcus aureus pneumonia. Chest 2005;128(3):1414-22.

22. Whitby M, McLaws ML, Berry G. Risk of death from methicillin-resistant Staphylococcus aureus bacteraemia: a meta-analysis. Med J Australia 2001;175(5): 264-7.

23. Cosgrove SE, Sakoulas G, Perencevich EN, Schwaber MJ, Karchmer AW, Carmeli Y. Comparison of mortality associated with methicillin-resistant and methicillinsusceptible Staphylococcus aureus bacteremia: a metaanalysis. Clin Infect Dis 2003;36(1):53-9.

24. Engemann JJ, Carmeli Y, Cosgrove SE, Fowler VG, Bronstein MZ, Trivette SL, Briggs JP, Sexton DJ, Kaye KS. Adverse clinical and economic outcomes attributable to methicillin resistance among patients with Staphylococcus aureus surgical site infection. Clin Infect Dis 2003;36(5):592-8

25. Rello J, Torres A, Ricart M, Valles J, Gonzalez J, Artigas A, Rodriguez-Roisin R. Ventilator-associated pneumonia by Staphylococcus aureus. Comparison of methicillin-resistant and methicillin-sensitive episodes. Am J Resp Critl Care Med 1994;150(6 Pt 1):1545-9.

26. Ibelings MM, Bruining HA. Methicillin-resistant Staphylococcus aureus: acquisition and risk of death in patients in the intensive care unit. Europ J Surg 1998; 164(6):411-8.

27. Gonzalez C, Rubio M, Romero-Vivas J, Gonzalez M, Picazo JJ. Bacteremic pneumonia due to Staphylococcus aureus: A comparison of disease caused by methicillin-resistant and methicillin-susceptible organisms. Clin Infect Dis 1999;29(5):1171-7.

28. Combes A, Luyt CE, Fagon JY, Wollf M, Trouillet JL, Gibert C, Chastre J; PNEUMA Trial Group. Impact of methicillin resistance on outcome of Staphylococcus aureus ventilator-associated pneumonia. Am J Resp Critl Care Med 2004;170(7):786-92.

29. Athanassa Z, Siempos, II, Falagas ME. Impact of methicillin resistance on mortality in Staphylococcus aureus VAP: a systematic review. Eur Respir J 2008;31(3): 625-32.

30. Vidaur L, Planas K, Sierra R, Dimopoulos G, Ramirez A, Lisboa T, Rello J. Ventilator-associated pneumonia: impact of organisms on clinical resolution and medical resources utilization. Chest 2008;133(3):625-32.

31. Shorr AF, Tabak YP, Gupta V, Johannes RS, Liu LZ, Kollef MH. Morbidity and cost burden of methicillinresistant Staphylococcus aureus in early onset ventilator-associated pneumonia. Critical Care 2006;10(3): R97.

32. Shorr AF, Combes A, Kollef MH, Chastre J. Methicillin-resistant Staphylococcus aureus prolongs intensive care unit stay in ventilator-associated pneumonia, despite initially appropriate antibiotic therapy. Crit Care Med 2006;34(3):700-6.

33. Shorr AF, Haque N, Taneja C, Zervos M, Lamerato L, Kothari S, Zilber S, Donabedian S, Perri MB, Spalding J, Oster G. Clinical and economic outcomes for patients with health care-associated Staphylococcus aureus pneumonia. J Clin Microbiol;48(9):3258-62.
34. Kallen AJ, Mu Y, Bulens S, Reingold A, Petit S, Gershman K, Ray SM, Harrison LH, Lynfield R, Dumyati G, Townes JM, Schaffner W, Patel PR, Fridkin SK; Active Bacterial Core surveillance (ABCs) MRSA Investigators of the Emerging Infections Program. Health care-associated invasive MRSA infections, 2005-2008. JAMA; 304(6):641-8.

35. National Nosocomial Infections Surveillance (NNIS) System report, data summary from January 1990-May 1999, issued June 1999. Am J Infect Control 1999; 27(6): 520-32.

36. Moalla M, Baratin D, Giard M, Vanhems P. Incidence of methicillin-resistant Staphylococcus aureus nosocomial infections in intensive care units in Lyon University hospitals, France, 2003-2006. Infect Control Hosp Epidemiol 2008;29(5):454-6.

37. Tacconelli E, De Angelis G. Pneumonia due to methicillin-resistant Staphylococcus aureus: clinical features, diagnosis and management. Current Opinion Pulm Med 2009;15(3):218-22.

38. Welte T, Pletz MW. Antimicrobial treatment of nosocomial meticillin-resistant Staphylococcus aureus (MRSA) pneumonia: current and future options. Int J Antimicrobial Agents 2010;36(5):391-400.

39. Walkey AJ, O'Donnell MR, Wiener RS. Linezolid versus Glycopeptide Antibiotics for the Treatment of Suspected Methicillin-Resistant Staphylococcus Aureus Nosocomial Pneumonia: A Meta-Analysis of Randomized Controlled Trials. Chest 2010 (epub Sep 23).

40. Jung YJ, Koh Y, Hong SB, Chung JW, Ho Choi S, Kim NJ, Kim MN, Choi IS, Han SY, Kim WD, Yun SC, Lim $\mathrm{CM}$. Effect of vancomycin plus rifampicin in the treatment of nosocomial methicillin-resistant Staphylococcus aureus pneumonia. Crit Care Med 2010; 38(1):175-80.

41. Falagas ME, Roussos N, Gkegkes ID, Rafailidis PI, Karageorgopoulos DE. Fosfomycin for the treatment of infections caused by Gram-positive cocci with advanced antimicrobial drug resistance: a review of microbiological, animal and clinical studies. Expert Opinion Investig Drugs 2009;18(7):921-44.

42. Resar R, Pronovost P, Haraden C, Simmonds T, Rainey T, Nolan T. Using a bundle approach to improve ventilator care processes and reduce ventilatorassociated pneumonia. Jt Comm J Qual Patient Saf 2005;31(5): 243-8.

43. Bird D, Zambuto A, O'Donnell C, Silva J, Korn C, Burke R, Burke P, Agarwal S. Adherence to ventilatorassociated pneumonia bundle and incidence of ventilator-associated pneumonia in the surgical intensive care unit. Arch Surg;145(5):465-70.

44. Rello J, Lode H, Cornaglia G, Masterton R. A European care bundle for prevention of ventilator-associated pneumonia. Intensive Care Med 2010;36(5):773-80.

45. Emilson CG. Susceptibility of various microorganisms to chlorhexidine. Scand J Dental Res 1977;85(4):255-65.

46. Koeman M, van der Ven AJ, Hak E, Joore HC, Kaasjager K, de Smet AG, Ramsay G, Dormans TP, Aarts LP, de Bel EE, Hustinx WN, van der Tweel I, Hoepelman AM, Bonten MJ. Oral decontamination with chlorhexidine reduces the incidence of ventilator-associated pneumonia. Am J Resp Crit Care Medicine 2006; 173(12):1348-55.

47. Scannapieco FA, Yu J, Raghavendran K, Vacanti A, Owens SI, Wood K, Mylotte JM. A randomized trial of chlorhexidine gluconate on oral bacterial pathogens in mechanically ventilated patients. Crit Care 2009;13(4): R117.

48. Ridenour G, Lampen R, Federspiel J, Kritchevsky S, Wong E, Climo M. Selective use of intranasal mupi- 
rocin and chlorhexidine bathing and the incidence of methicillin-resistant Staphylococcus aureus colonization and infection among intensive care unit patients. Infect Control Hosp Epidemiol 2007;28(10):1155-61.

49. Evans HL, Dellit TH, Chan J, Nathens AB, Maier RV, Cuschieri J. Effect of chlorhexidine whole-body bathing on hospital-acquired infections among trauma patients. Arch Surg;145(3):240-6.

50. Climo MW, Sepkowitz KA, Zuccotti G, Fraser VJ, Warren DK, Perl TM, Speck K, Jernigan JA, Robles JR, Wong ES. The effect of daily bathing with chlorhexidine on the acquisition of methicillin-resistant Staphylococcus aureus, vancomycin-resistant Enterococcus, and healthcare-associated bloodstream infections: results of a quasi-experimental multicenter trial. Crit Care Med 2009;37(6): 1858-65.

51. Krishna BV, Gibb AP. Use of octenidine dihydrochloride in meticillin-resistant Staphylococcus aureus decolonisation regimens: a literature review. J Hosp Infect 2010; 74(3):199-203.

52. Rammelkamp CH, Jr., Mortimer EA, Jr., Wolinsky E. Transmission of Streptococcal and Staphylococcal Infections. Annals Int Med 1964;60:753-8.

53. Grundmann H, Hori S, Winter B, Tami A, Austin DJ. Risk factors for the transmission of methicillin-resistant Staphylococcus aureus in an adult intensive care unit: fitting a model to the data. J Infect Dis 2002;185(4):481-8.

54. Pittet D, Hugonnet S, Harbarth S, Mourouga P, Sauvan V, Touveneau S, Perneger TV.. Effectiveness of a hospital-wide programme to improve compliance with hand hygiene. Lancet 2000;356(9238):1307-12.

55. Sroka S, Gastmeier P, Meyer E. Impact of alcohol hand-rub use on meticillin-resistant Staphylococcus aureus: an analysis of the literature. J Hosp Infect 2010; 74(3):204-11.

56. Lucet JC, Regnier B. Screening and decolonization: does methicillin-susceptible Staphylococcus aureus hold lessons for methicillin-resistant S. aureus? Clin Infect Dis 2010; 51(5):585-90.

57. Robicsek A, Suseno M, Beaumont JL, Thomson RB, Jr., Peterson LR. Prediction of methicillin-resistant Staphylococcus aureus involvement in disease sites by concomitant nasal sampling. J Clin Microbiol 2008;46(2): 588-92.

58. Harbarth S, Fankhauser C, Schrenzel J, Christenson J, Gervaz P, Bandiera-Clerc C, Renzi G, Vernaz N, Sax $\mathrm{H}$, Pittet D. Universal screening for methicillin-resistant Staphylococcus aureus at hospital admission and nosocomial infection in surgical patients. JAMA 2008; 299(10):1149-57.

59. Tacconelli E, De Angelis G, de Waure C, Cataldo MA, La Torre G, Cauda R. Rapid screening tests for meticillin-resistant Staphylococcus aureus at hospital admission: systematic review and meta-analysis. Lancet Infect Dis 2009; 9(9):546-54.

60. Albrich WC, Harbarth S. Health-care workers: source, vector, or victim of MRSA? Lancet Infect Dis 2008; 8(5): 289-301.

61. Siegel JD, Rhinehart E, Jackson M, Chiarello L. Management of multidrug-resistant organisms in health care settings, 2006. AmJ Infect Control 2007;35(10 Suppl 2): S165-S93.
62. Cooper BS, Stone SP, Kibbler CC, Cookson BD, Roberts JA, Medley GF, Duckworth G, Lai R, Ebrahim S. Isolation measures in the hospital management of methicillin resistant Staphylococcus aureus (MRSA): systematic review of the literature. BMJ 2004; 329(7465): 533.

63. Cepeda JA, Whitehouse T, Cooper B, Hails J, Jones K, Kwaku F, Taylor L, Hayman S, Cookson B, Shaw S, Kibbler C, Singer M, Bellingan G, Wilson AP. Isolation of patients in single rooms or cohorts to reduce spread of MRSA in intensive-care units: prospective two-centre study. Lancet 2005;365(9456):295-304.

64. Evans HL, Shaffer MM, Hughes MG, Smith RL, Chong TW, Raymond DP, Pelletier SJ, Pruett TL, Sawyer RG. Contact isolation in surgical patients: a barrier to care? Surgery 2003;134(2):180-8.

65. Stelfox HT, Bates DW, Redelmeier DA. Safety of patients isolated for infection control. JAMA 2003; 290(14):1899-905.

66. Barwolff S, Sohr D, Geffers C, Brandt C, Vonberg RP, Halle H, Rüden H, Gastmeier P. Reduction of surgical site infections after Caesarean delivery using surveillance. J Hosp Infect 2006;64(2):156-61.

67. Larue A, Loos-Ayav C, Jay N, Commun N, Rabaud C, Bollaert PE. [Impact on morbidity and costs of methicillin-resistant Staphylococcus aureus nosocomial pneumonia in intensive care patients]. Presse Med 2009;38(1): 25-33.

68. Gastmeier P, Sohr D, Geffers C, Behnke M, Daschner F, Ruden H. Mortality risk factors with nosocomial Staphylococcus aureus infections in intensive care units: results from the German Nosocomial Infection Surveillance System (KISS). Infection 2005;33(2):50-5.

69. Zahar JR, Clec'h C, Tafflet M, Garrouste-Orgeas M, Jamali S, Mourvillier B, De Lassence A, Descorps-Declere A, Adrie C, Costa de Beauregard MA, Azoulay E, Schwebel C, Timsit JF; Outcomerea Study Group. Is methicillin resistance associated with a worse prognosis in Staphylococcus aureus ventilator-associated pneumonia? Clin Infect Dis 2005;41(9):1224-31.

70. Pujol M, Corbella X, Pena C, Pallares R, Dorca J, Verdaguer R, Diaz-Prieto A, Ariza J, Gudiol F. Clinical and epidemiological findings in mechanically-ventilated patients with methicillin-resistant Staphylococcus aureus pneumonia. Eur J Clin Microbiol Infect Dis 1998;17(9):622-8.

71. Neely AN, Maley MP. Survival of Enterococci and Staphylococci on Hospital Fabrics and Plastic. J Clin Microbiol 2000; 38 (2): 724-726.

Received: October 28, 2010 / Accepted: November 9, 2010

Address for correspondence:

E. Meyer MD

Institute of Hygiene and Environmental Medicine

Charité University Medicine

Hindenburgdamm 27

12203 Berlin

Germany

Phone: +49-30- 8445-4883

Fax: +49-30-8445-3682

E-mail: elisabeth.meyer@charite.de 


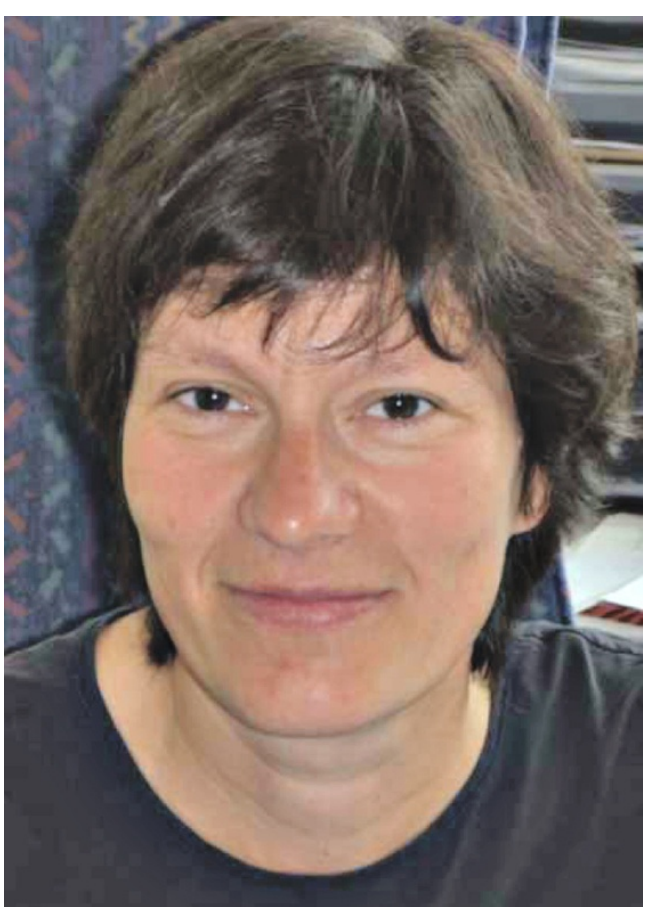

Elisabeth Meyer

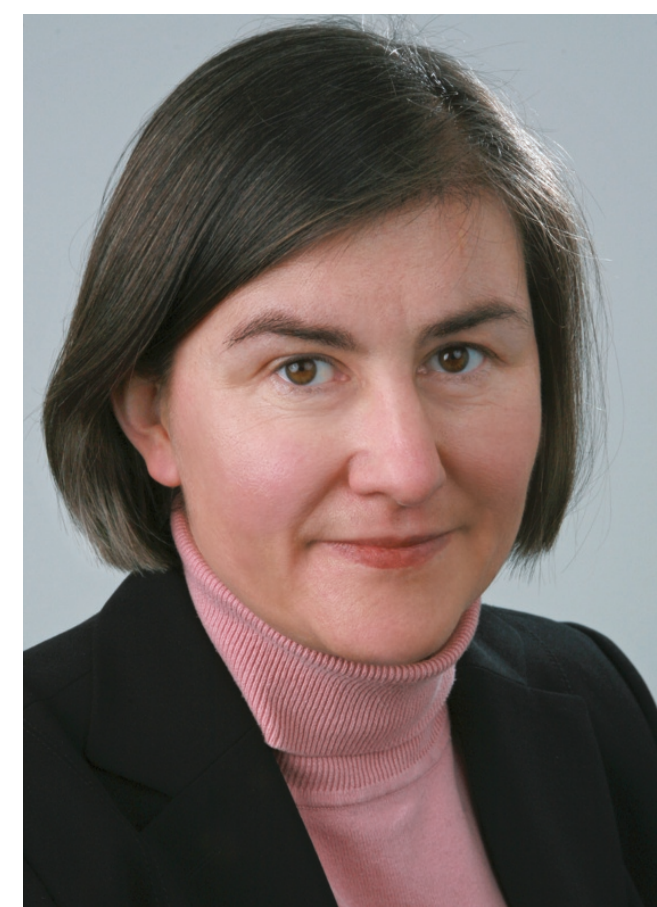

Petra Gastmeier 